\title{
Isolation and Morphological Characterization of Endophytic Fungi Isolated from Ten Different Varieties of Mango
}

\author{
Mahesh S. Dashyal $^{1}$, C.G. Sangeetha ${ }^{1 *}$, Vikram Appanna $^{2}$, \\ G.K. Halesh ${ }^{3}$ and V. Devappa ${ }^{1}$
}

${ }^{1}$ Department of Plant Pathology, College of Horticulture, University of Horticultural Sciences Campus, GKVK, Bengaluru, 560 065, Karnataka, India

${ }^{2}$ Department of Agricultural Microbiology, College of Horticulture, University of

Horticultural Sciences Campus, Mysuru-571130, Karnataka, India

${ }^{3}$ Department of Biotechnology and Crop Improvement, College of Horticulture, University of Horticultural Sciences Campus, GKVK, Bengaluru, 560 065, Karnataka, India

*Corresponding author

\section{A B S T R A C T}

Keywords

Endophytes,

Mango,

Anthracnose, Fungi,

morphology

Article Info

Accepted:

07 February 2019

Available Online:

10 March 2019
Endophytes are the microbes that colonize the healthy tissues of plant. Endophytes associated with Mangifera indica (mango) are less understood. In this study, endophytic fungi were isolated fromten different mango varieties viz., Alphonso, Totapuri, Neelam, Anfas, Willard, Badam model, Khaderi, Pancharasi, White Sari and KisanBhog from Bengaluru, Karnataka, India. Endophytic fungi were isolated fromleaf and stem tissues. Nine endophytic fungi were isolated from Alphonso out of which four were from leaf and five were from stem tissues. Two endophytic fungi were isolated from the leaf tissue of Totapuri, and five from the stem tissue. From Neelam, only four endophytic fungi were isolated from stem tissue and no endophytic fungi grew from the leaf tissue. One endophytic fungi was isolated from leaf and stem tissue each from Anfas, Willard, Badam Model, Kadari, Pancharasi and White sari, whereas two fungi were isolated from leaf tissue of KisanBogh and one from stem tissue. The isolates were studied for to their morphological characters and naming was done based on the variety and the part isolated.

\section{Introduction}

Mango (Mangifera indica L.) is considered as one of the choicest fruitcrops grown all around the world (Shad et al., 2002). It is grown in more than 100 nations, however nowhere it is enormously esteemed as in India where 40 per cent of the total fruits grown is mango (Swamy, 2012). In India, mango is grown in 21.63 lakh hectares with a production of 185.27 lakh MT. In Karnataka, it is grown in 1.78 lakh hectares with a production of 1.78 metric tonnes and productivity is $10 \mathrm{t} / \mathrm{ha}$ (Anon., 2014). Mango is affected by a number of diseases at all the stages of its development right from seedling in nursery to the fruit in storage or transit

Endophytes are bacterial or fungal microorganisms that colonize plant tissue 
intercellularly as well as intracellularly without causing any clear manifestations (Wilson, 1995). Endophyte, by definition, is one which lives in the tissues underneath the epidermal cell layers and makes no evident damage to the host (Stone et al., 2000). They are present in all the plants parts, colonize all plants, and have been found from all plants analyzed till date (Nair and Padmavathy, 2014). To keep up consistent beneficial interaction, endophytes deliver different compounds that advance development of plants and help plant to better environmental adoption. Plants growing in areas of great biodiversity also have the prospect of housing endophytes with great biodiversity (Strobel et al., 2003).Out of 1.5 million fungal species evaluated to be available, only 97,861 fungal species have been studied (Hawksworth, 1991). They deliver an immense range of compounds which are valuable for plants for their development, insurance to natural circumstances and supportability (Nair and Padmavathy, 2014). They additionally assume an essential part in nutrient cycling, biodegradation and bioremediation (Das and Varma, 2009; Lee et al., 2004). Hence in this study we aimed at studying the diversity of endophytic fungi associated with ten different varieties of mango in terms of presence and their characteristics.

\section{Materials and Methods}

The foregoing investigations were conducted at the Department of Plant Pathology, College of Horticulture, Bangalore, University of Horticultural Sciences, Bagalkot.

\section{Isolation of endophytic fungi}

\section{Collection of sample}

For isolation of endophytic fungi, mature, healthy, green, asymptomatic leaves and stem tissues were collected from ten mango varieties. Healthy leaf and stem tissues of 10 mango varieties viz., Alphonso, Totapuri and Neelam were collected from the orchards of University of Horticultural Sciences, Bagalkot, Regional Horticulture Research Station, Bengaluru. Similarly, healthy leaf and stem tissues of Anfas, Willard, Khaderi, Pancharasi, Kisanbhog, White Sari and Badam model were collected from Indian Institute of Horticultural Research Station, Bengaluru. Samples were collected from three randomly selected plants from each variety and collected leafs are clubbed and collected in a plastic bags, labeled, transported to lab within 12 hours and used for isolation. Although rapid changes in endophyte colonization probably do not occur immediately following collection, all samples were handled carefully and processed as quickly as possible. Samples were air-dried to remove any surface moisture before transport or storage. During transport, samples were kept cool and dry. Samples of Alphonso, Totapuri, Neelam were collected from six year old trees and the samples from the other remaining varieties viz., Anfas, Willard, Khaderi, Pancharasi, KisanBhog, White Sari and Badam model were collected from 40 years old trees.

\section{Isolation of fungal endophytes}

Endophytic fungi were isolated from leaf and stem tissues collected from the different mango varieties like Anfas, Willard, Khaderi, Pancharasi, KisanBhog, Alphanso, Totapuri, Neelum, White Seri and Badam Model.

All the leaf and stem samples were washed under running water prior to surface sterilization. Leaf discs were cut from leaf using a sterile blade to isolate endophytes. Stem segments were cut from internal tissues of stems. Size of the sampling unit and surface sterilization procedures vary according to the preferences of the 
investigator, the species of host plant, and host tissue type sampled. In our study we followed the modified method of Michereff et al., (2014) as discussed below:

Leaf segments were surface sterilized in 75 per cent ethanol for 1 minute and 2 per cent sodium hypochlorite for 1 minute. The stem fragments were surface sterilized in 75 per cent ethanol for 1 minute and 2 per cent sodium hypochlorite for 2 minute. Sterilized segments were rinsed in sterilized distilled water and then dried on sterilized paper. The effectiveness of the sterilization procedure was tested using the imprint method (Schulz et al., 1993). Three fragments were placed evenly in petri dishes (9 $\mathrm{cm}$ dia.) containing potato dextrose agar (PDA) medium amended with streptomycin to suppress bacterial growth and incubated at $28^{\circ} \mathrm{C}$. The fungi growing out of the segments during the incubation period were recorded as endophytes and then those endophytes were pure cultured.

\section{Characterization of fungal endophytes}

\section{Morphological study}

Cultures on PDA media were assessed according to their morphology. Colony character of the fungal growth, topography was noted and characters of mycelial colour, type and spore production were observed.

\section{Results and Discussion}

\section{Isolation of fungal endophytes from different mango varieties}

Endophytic fungi were isolated from leaf and stem of different mango varieties like Alphanso, Totapuri, Neelum, Anfas, Willard, Khaderi, Pancharasi, KisanBhog, White Sari and Badam Model. Totally 35 fungal endophytes were isolated from mango varieties, out of which 14 isolates were from leaf and 21 isolates were from stem tissues (Table 1). The result showed that more number of endophytic fungi was isolated from stem tissue as compared to the leaf tissues. The isolates were designated with first two alphabets denoting endophytic fungi (EF), next letter the first letter of the variety from which the fungi was isolated (Eg.:AAlphonso), the fourth letter the tissue from which it was isolated, wherein L stands for leaf and $\mathrm{S}$ stands for stem. The endophytes isolated are designated as $\mathrm{A}, \mathrm{B}, \mathrm{C}, \mathrm{D}$ and so forth.

Similar isolations from plants were done by other workers like Nayak (2015) who isolated 17 fungal endophytic species from the ornamental mango (Mangiferaindica) and Michereffet al., (2014) isolated 169 fungal endopytes from noncommercial mango plant; Amin et al., 2014 isolated endophytes from cultivars which were resistant and susceptible to vascular streak disease.

\section{Morphological characterization of fungal endophytes}

Morphological characteristics of all the 35 isolates like mycelial characters and spore production were examined using cultures grown on PDA. There was a lot of variation in the morphological characters of all the endophytic fungi isolated from different varieties (Table 2 ).

Out of nine fungal endophytes isolated from Alphonso variety, two endophytes EFAL-A and EFAS-E exhibited slow growth and two isolated EFAL-B and EFAS-C exhibited medium growth. Five endophyes isolated from leaf as well as stem, EFAL-C, EFAL-D, EFAS-A, EFAS-B and EFAS-D exhibited fast growth. Five endophytes EFAL-A, EFAL-C, EFAL-D, EFAS-C and EFAS-D showed greyish mycelium. All the isolates were non- 
sporulating except EFAS-E. Four endophytes isolated from leaf EFAL-A, EFAL-B, EFAL$\mathrm{C}$ and EFAL-D showed septate mycelium and five endophytes isolated from stem EFAS-A, EFAS-B, EFAS-C, EFAS-D and EFAS-E showed aseptate mycelium.

Two endophytes EFAL-D and EFAS-A showed cottony type mycelium and three endophytic fungi viz., EFAL-B, EFAL-C and EFAS-D showed fluffy mycelium on PDA (Figure 1).

The results revealed that, out of total 35 fungal isolates, 17 endophytes EFAL-A, EFAL-B， EFAL-C, EFAL-D, EFTS-A, EFTS-B, EFTS-D, EFTS-E, EFNS-A, EFNSB, EFNS-C, EFWL-A, EFWS-A, EFBML-A, EFKAL-A, EFPL-A, EFWSL-A, EFKBL-B and EFKBS-A showed septate mycelium which was dark coloured and the remaining 18 endophytes showed aseptate mycelium and were hyaline in colour.

Majority of them did not produce spores and only two endophytes EFTS-E and EFKBL-A isolated from the stem tissue of totapuri and leaf tissue of Kisanbhog respectively produced hyaline spores (Figure 2).
The fungal isolates EFAL-A, EFAS-E, EFATL-A， EFATL-B， EFTS-A， EFTS-B, EFTS-C, EFWDL-A, EFBML-A, EFKAL-A and EFKAS-B were slow growing and EFALB, EFAS-C, EFTS-D, EFTS-E, EFNS-B, EFNS-C, EFNS-D, EFANS-A, EFBMS-A, EFPL-A, EFPS-A, EFWSL-A, EFKBL-A and EFKBL-B showed medium growth rate and EFAL-C, EFAL-D, EFAS-A, EFAS-B, EFAS-D, EFNS-A, EFWS-A, EFANFL-A, EFWS-A and EFKBS-A were reported to be fast growing.

Six isolates out of 35 showed fluffy cottony growth of mycelia (EFAL-B, EFAL-C, EFAS-D, EFNS-B, EFNS-C and EFKBS-A) on PDA and 11 isolates out of 35 showed cottony growth (EFAL-D, EFAS-A, EFATLA, EFATL-B, EFTS-A, EFTS-C, EFTS-D, EFTS-E, EFNS-D, EFWS-A and EFKBL-B). Nine endophytic fungi (EFAL-A, EFAL-C, EFAL-D, EFAS-C, EFAS-D, EFNS-B, EFWS-A, EFBML-A and EFKL-A) out of 35 isolates showed greyish colony on PDA media, three (EFTL-A, EFTS-B and EFTS-E) showed blackish growth on PDA. Six (EFASB, EFTL-B, EFTS-C, EFNS-C, EFWDL-A and EFKBS-A) endophytes showed mixed colony colour on PDA media.

Table.1 The endophytic fungi isolated from ten different varieties of mango

\begin{tabular}{|c|c|c|c|}
\hline \multirow{2}{*}{ Sl. No } & Varieties & \multicolumn{2}{|c|}{ Fungal strains isolated } \\
\cline { 3 - 4 } & & Leaf & Stem \\
\hline $\mathbf{1}$ & Alphonso & 4 & 5 \\
\hline $\mathbf{2}$ & Totapuri & 2 & 5 \\
\hline $\mathbf{3}$ & Neelam & 0 & 4 \\
\hline $\mathbf{4}$ & Anfas & 1 & 1 \\
\hline $\mathbf{5}$ & Willard & 1 & 1 \\
\hline $\mathbf{6}$ & Badam model & 1 & 1 \\
\hline $\mathbf{7}$ & Khaderi & 1 & 1 \\
\hline $\mathbf{8}$ & Pancharasi & 1 & 1 \\
\hline $\mathbf{9}$ & White Sari & 1 & 1 \\
\hline $\mathbf{1 0}$ & KisanBogh & 2 & 1 \\
\hline & Total & $\mathbf{1 4}$ & $\mathbf{2 1}$ \\
\hline
\end{tabular}


Table.2 Morphological characteristics of endophytic fungi isolated from ten different varieties of mango

\begin{tabular}{|c|c|c|c|c|c|c|c|}
\hline Sl. No & Variety & Isolate & $\begin{array}{c}\text { Spore } \\
\text { production }\end{array}$ & $\begin{array}{l}\text { Mycelium } \\
\text { characters }\end{array}$ & $\begin{array}{l}\text { Topography of the } \\
\text { fungal growth }\end{array}$ & Color of the colony & $\begin{array}{c}\text { Growth } \\
\text { rate }\end{array}$ \\
\hline & \multicolumn{7}{|c|}{ Alphonso } \\
\hline 2 & \multirow{3}{*}{ Leaf } & EFAL-B & No & Septatecoloured & Fluffy & Dull whitish & Medium \\
\hline 3 & & EFAL-C & No & Septatecoloured & Fluffy uniform & Greyish & Fast \\
\hline 4 & & EFAL-D & No & Septatecoloured & Cottony type mycelium & Greyish & Fast \\
\hline 6 & \multirow{4}{*}{ Stem } & EFAS-B & No & Aseptate hyaline & Flat Silky & White and yellow & Fast \\
\hline 7 & & EFAS-C & No & Aseptate hyaline & Flat spongy & Greyish & Medium \\
\hline 8 & & EFAS-D & No & Aseptate hyaline & Fluffy uniform & Greyish black & Fast \\
\hline \multirow[t]{2}{*}{9} & & EFAS-E & Yes & Aseptate hyaline & $\begin{array}{l}\text { Flat milky growth of } \\
\text { mycelium }\end{array}$ & Yellowish white & Slow \\
\hline & \multicolumn{7}{|l|}{ Totapuri } \\
\hline 13 & \multirow{4}{*}{ Stem } & EFTS -B & No & Septatecoloured & $\begin{array}{c}\text { Corky growth with wavy } \\
\text { margin slightly } \\
\text { undulated }\end{array}$ & Blackish grey & Slow \\
\hline 14 & & EFTS $-\mathrm{C}$ & No & Aseptate hyaline & Cottony flat & $\begin{array}{l}\text { Reddish center with } \\
\text { white margin }\end{array}$ & Slow \\
\hline 15 & & EFTS -D & No & Septatecoloured & Cottony flat type & $\begin{array}{l}\text { Dark brownish centre } \\
\text { with brown margin }\end{array}$ & Medium \\
\hline 16 & & EFTS -E & No & Septatecoloured & Cottony flat & Black & Medium \\
\hline \multirow[t]{2}{*}{17} & \multicolumn{7}{|l|}{ Neelum } \\
\hline & Stem & EFNS-A & No & Septatecoloured & Flat uniform & Brownish yellow & Fast \\
\hline
\end{tabular}




\begin{tabular}{|c|c|c|c|c|c|c|c|}
\hline 18 & & EFNS -B & No & Septatecoloured & Fluffy uniform & Greyish & Medium \\
\hline 19 & & EFNS -C & No & Septatecoloured & $\begin{array}{l}\text { Fluffy cottony growth } \\
\text { raised at center }\end{array}$ & White and greyish & Medium \\
\hline 20 & & EFNS -D & No & Aseptate hyaline & Cottony uniform & Whitish purple & Medium \\
\hline 21 & Leaf & EFANL-A & No & Aseptate hyaline & Flat uniform & Dull brown & Fast \\
\hline 22 & Stem & EFANS-A & No & Aseptate hyaline & Flat uniform growth & Whitish yellow & Medium \\
\hline \multirow[t]{2}{*}{24} & Stem & EFWS-A & No & Septatecoloured & flat cottony growth & Grey & Fast \\
\hline & \multicolumn{7}{|c|}{ Badam Modal } \\
\hline 25 & Leaf & EFBML-A & No & Septatecoloured & Raised colony & Grey & Slow \\
\hline \multirow[t]{2}{*}{26} & Stem & EFBMS-A & No & Aseptate hyaline & Uniform undulated & Whitish yellow & Medium \\
\hline & \multicolumn{7}{|l|}{ Kadari } \\
\hline 27 & Leaf & EFKL-A & No & Septatecoloured & Raised undulated & Grey & Slow \\
\hline 29 & Leaf & EFPL-A & No & Septatecoloured & Flat uniform & Brownish black & Medium \\
\hline \multirow[t]{2}{*}{30} & Stem & EFPS-A & No & Aseptatehyaline & Flat undulated & Yellowish white & Medium \\
\hline & \multicolumn{7}{|c|}{ White Seri } \\
\hline 31 & Leaf & EFWSL-A & No & Septatecoloured & Flat wavy & Dark brown & Medium \\
\hline \multirow[t]{2}{*}{32} & Stem & EFWSS-A & No & Aseptate hyaline & $\begin{array}{l}\text { Flat undulated wavy } \\
\text { growth }\end{array}$ & Yellow & Medium \\
\hline & \multicolumn{7}{|c|}{ KisanBogh } \\
\hline 33 & \multirow[t]{2}{*}{ Leaf } & EFKBL-A & Yes & Aseptate hyaline & Flat milky growth & Dull yellow & Medium \\
\hline 34 & & EFKBL-B & No & Septatecoloured & Flat cottony growth & Brownish black & Medium \\
\hline 35 & Stem & EFKBS-A & No & Septatecoloured & $\begin{array}{l}\text { Uniform raised fluffy } \\
\text { growth }\end{array}$ & Grey and dull white & Fast \\
\hline
\end{tabular}


Fig.1 Colony morphology of fungal endophytes isolated from Alphonso variety

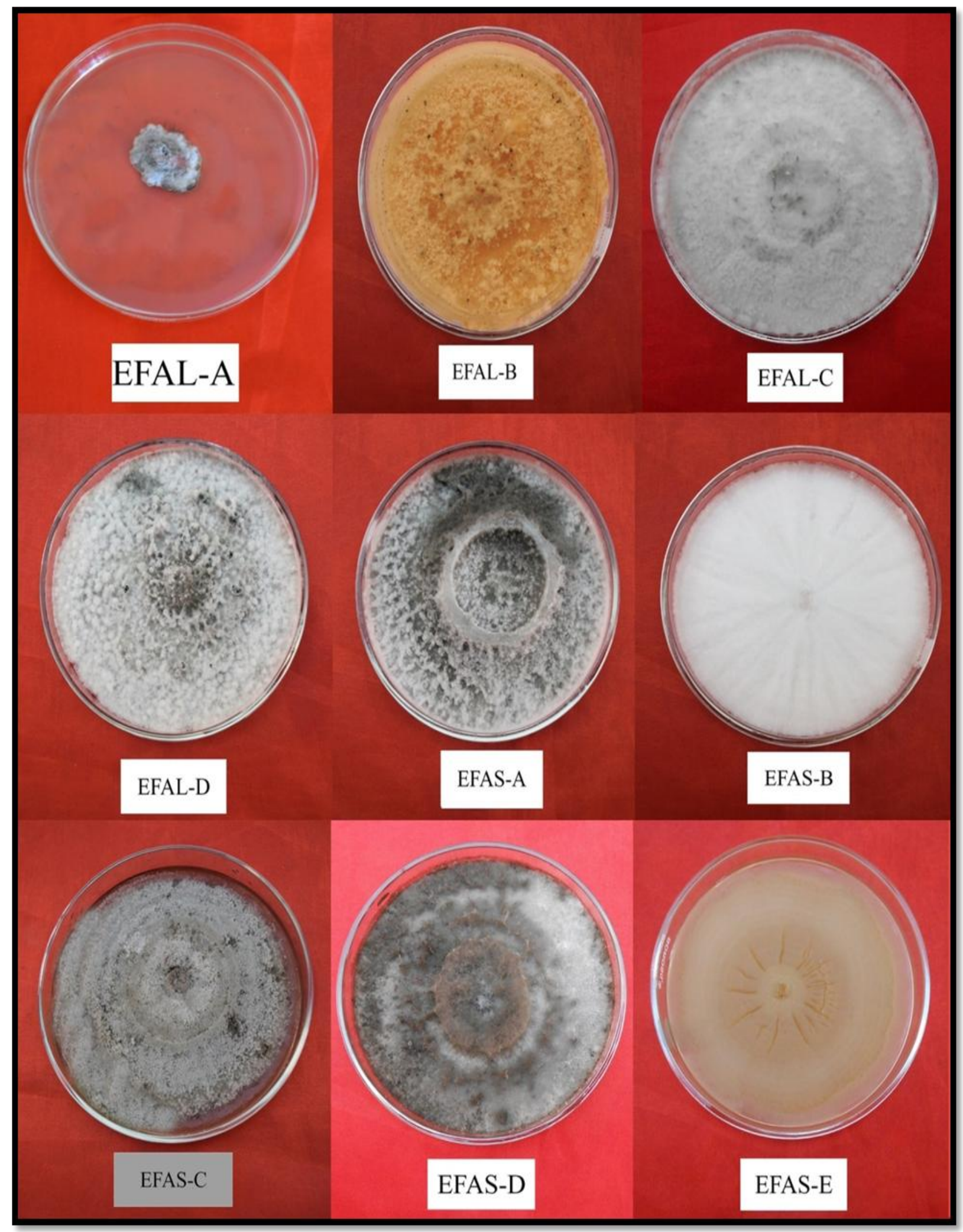


Fig.2 Microscopic characters of some fungal endophytes isolated from different mango tissues
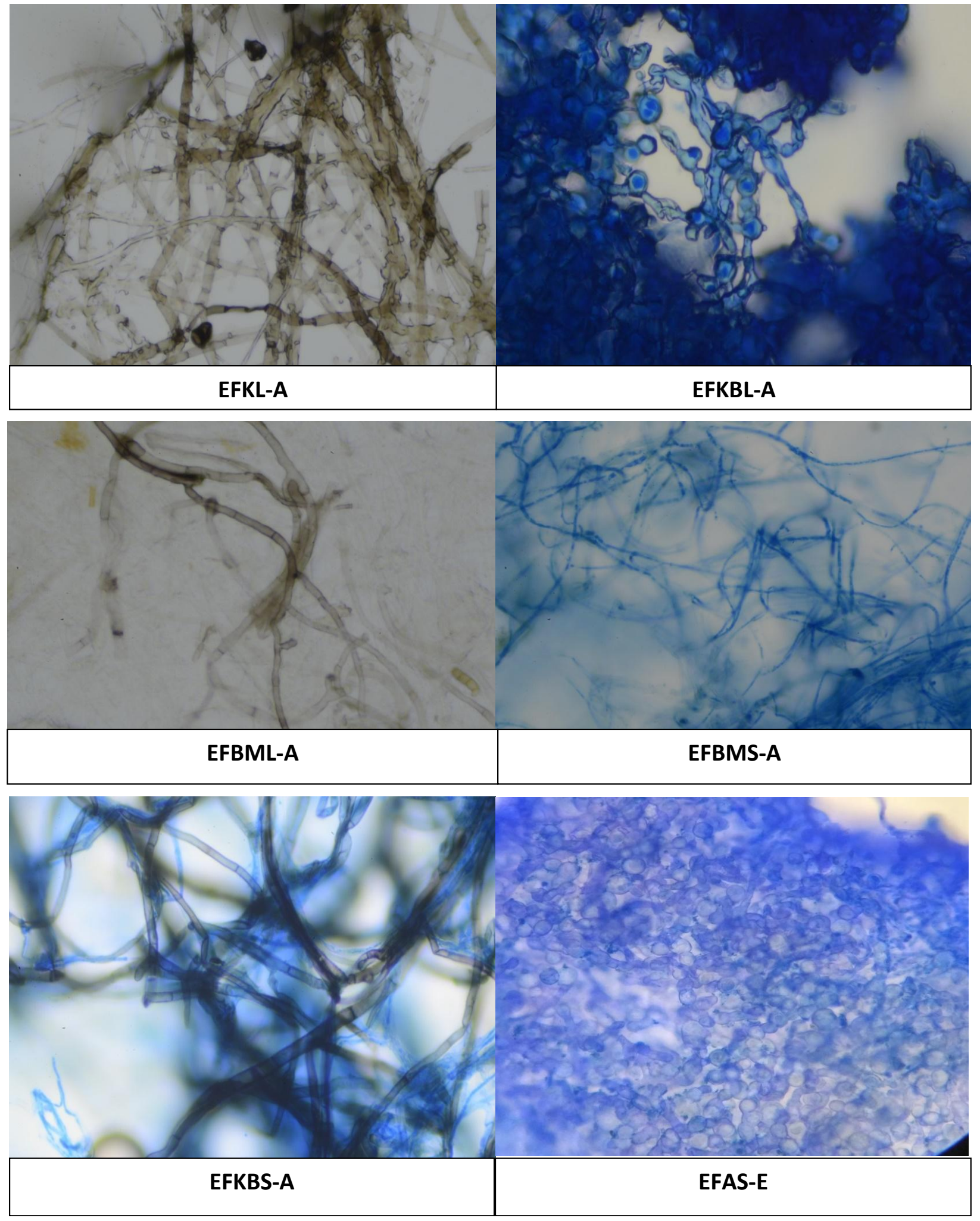
Similar morphological studies in fungi done by Huang et al., 2009 isolated 108 fungal isolates from three medicinal Artemisia species was first carried out according to colony or hyphal morphology of the fungal culture, characteristics of the spores; Carmichael et al., (1980), Barnett and Hunter, (1998), Ainsworth et al., (1973), Shekhawat et al., (2010) studied morphological studies from endophytic fungi isolated from leaves of Melia azedarach L. (Meliaceae); Correa et al., 2014 studied morphological studies on endophytic fungi from Actinidia macrosperma.

In conclusion, endophytic miccrobes are known to exist in unique ecological niches and influence the distribution, ecology, physiology and characteristic of the plants. The present investigation was undertaken to know the diversity and distribution of the endophytic fungi in ten different varieties of mango. The study revealed that there exists diversity in the number and morphological characteristics of the endophytic fungi isolated from the various tissue of the host. There was also variations in the mycelialcolour, sepatations and the colony characters similar to the variation in the host characters. Further studies on the identification of the fungi, their role in the growth and development of the plant and their ability to suppress the pathogens will play a significant role in horticulture.

\section{Acknowledgment}

I would like to acknowledge Department of Plant Pathology, College of Horticulture, Bengaluru, UHS, Bagalkot for smooth conduct of experiment during my M.Sc. research work.

\section{References}

Ainsworth, G. C., 1973, Ainsworth and
Bisby's Dictionary of the fungi. VI. Edn. Commonwe. mycol. Inst., Kew, Surrey, England, pp. 663.

Amin, N., Salam, M., Junaid, M., Asman and Baco, M. S. 2014. Isolation and identification of endophytic fungi from cocoa plant resistant VSD M.05 and cocoa plant Susceptible VSD M.01 in South Sulawesi, Indonesia. Int. J. Curr. Microbiol. App. Sci., 3(2):459-467.

Anonymous. 2014. Indian Horticulture Database, National Horticultural Board,Ministry of Agriculture, Government of India, Gurgaon.

Barnett, H.L., And B. B. Hunter, 1998, The Illustrated Genera of Imperfect Fungi. Fourth Edition Aps Press, American Phytopathol. society, St. Paul, Minnesota. pp.218.

Carmichael, J.W., Kendrick, W.B., Conners, I.L. and Sigler, L., 1980, Genera of Hyphomycetes. The University of Alberta Press, Edmonton, Alberta, Canada.pp.386.

Correa, R. C. G., Rhoden, S. A., Mota, T. R., Azevedo, J. L., Pamphile, J. A., Souza, C. G. M., Polizeli, M. L. T., 2014, Endophytic fungi: expanding the arsenal of industrial enzyme producers. J. Ind. Microbiol. Biotechnol., 41: 1467-1478.

Das, A. and Varma, A., 2009, Symbiosis: the art of living, In Symbiotic Fungi Principles and Practice. Ed. Varma, A. and Kharkwal, A. C., Springer Publication, pp. 1-28.

Hawksworth, D. L., 1991, The fungal dimension of biodiversity: magnitude, significance, and conservation, Mycol. Res., 95(6): 641-655.

Huang W.Y, CAI Y. Z., Surveswaran, S., Hyde K. D., Corke, H., Sun, M., 2009, Molecular phylogenetic identification of endophytic fungi isolated from three Artemisia species. Fungal Diversity 36: 69-88.

Lee, S., Flores-Encarnacion, M., Contreras- 
Zentella, M., Garcia-Flores, L., Escamilla, J. E. and Kennedy, C., 2004, Indole-3-aceticacid biosynthesis is deficient Gluconacetobacterdiazotrophicus strains with mutations in Cytochrome c biogenesis genes, J. Bacteriol., 186(16): 5384-5391.

Michereff, S., Morais, M. A., Hyde, K. D. and Marcos, P. S. C., 2014, Endophytic species of Colletotrichum associated with mango in north eastern Brazil. Fungal Diversity, 67(1): 181-202.

Nair, D. and Padmavathy, S., 2014, Impact of endophytic microorganisms on plants, environment and humans. Sci.world j., 2014: 250693.

Nayak, B. K., 2015, Studies on endophytic fungal diversity from different leaf samples of Pongamia pinnata. Int. J. Medi. Pharm. Res., 1:134-138.

Schulz, B., Wanke, U., Drager, S. and Aust, H. J., 1993. Endophytes from herbaceous plants and shrubs: effectiveness of surface sterilization methods. Mycol. Res., 97: 1447-1450

Shad, M.A., Ansari, T.M., Pervez, H., Rubab, M. and Mahmood, T., 2002, Department of Chemistry,
BahauddinZakariya University, Multan60800, Pakistan Mango Research Station, Shujabad, Punjab, Pakistan.Online Journal of Biological Science, 2(10): 694-696.

Shekhawat KK, Rai DV, Batra A., 2010, Morphological study of endophytic fungi inhabiting leaves of Meliaazedarach L. Int. J. Pharmaceutical Sci. Review Research5(3), 177-180.

Stone JK, Bacon CW, White JF, 2000, An overview of endophytic microbes: endophytism defined. In: Bacon $\mathrm{CW}$, White JF (eds) Microbial endophytes. Dekker, New York, pp.3-30.

Strobel, G. and Bryn D., 2003, Bioprospecting for microbial endophytes and their natural products, Microbiol. Mol. Biol., 67(4): 491-502.

Swamy, J. S., 2012, Anthracnose- A devastating pre and post-harvest disease in mango, Int. J. Pl. Protec., 5(2): 429437.

Wilson, D., 1995, Endophyte: the evolution of a term, and clarification of its use and definition, Oikos, 73(2): 274-276.

\section{How to cite this article:}

Mahesh S. Dashyal, C.G. Sangeetha, Vikram Appanna, G.K. Halesh and Devappa, V. 2019. Isolation and Morphological Characterization of Endophytic Fungi Isolated from Ten Different Varieties of Mango. Int.J.Curr.Microbiol.App.Sci. 8(03): 717-726. doi: https://doi.org/10.20546/ijcmas.2019.803.088 